\title{
PREVENTION OF ELDERLY DEMENTIA BY SOCIAL WORK METHODS
}

\author{
Olesia Makohin ${ }^{1}$, Marta Kozak² \\ Lviv Polytechnic National University, Lviv, Ukraine \\ ${ }^{1}$ Student of bachelor program "Social work", of Department of Sociology and Social Work, \\ ${ }^{2}$ Candidate of Biological Science, Associate Professor of Department of Sociology and Social Work
}

Background: the problem of dementia is one of the important social problems of the 21 st century that needs to be addressed by a social worker. According to the definition of the World Health Organization, dementia is "a syndrome that is usually chronic or progressive, sometimes the degradation of cognitive function (the ability to think and analyze adequately) more than expected in normal aging.". Not only does dementia lead to memory problems, but over time, personality change, loss of most social skills, behavioral change, and reactions to the environment.

Purpose: the theoretical study is to study the problem of dementia and its prevention for older people through social work.

Methods: Theoretical, which should include the synthesis of scientific and educational literature and analysis of literature. Theoretical research methods were set general and specific methods and techniques ofscientific knowledge are used based goal, object and subject.

Results: In social work with the dementia of the elderly, attention should be paid to the specificity of the life of an elderly person, which consists of many factors that are sometimes destructive. The following factors include:

1. Poor health.

2. Weakening of mental functions. Deterioration of attention, slowing of cognitive processes, dispersion lead to disadaptation of an elderly person to the environment.

3. Low standard of living.

4. Reducing social connections, loneliness.

5. Changing social skills.

All these factors may not affect the mental state of an elderly person and dementia, one of the variants of the manifestation of social and psychological disability.

Conclusion: Complex social and rehabilitation work in studying the social characteristics of an elderly person makes it possible to suspend the process of dementia. The above methods of social work contribute to the long-term preservation of cognitive function and daily activity of the elderly. The process of dementia in Ukraine is poorly understood, so foreign experience must be taken into account for successful practice, but bear in mind that the factors of residence in countries with different levels of life differ, and therefore need to be adjusted according to the needs and features of Ukrainian aging.

Keywords: dementia, prevention of dementia, the elderly, methods of social work.

Соціально-демографічна структура сучасного суспільства характеризується постійним збільшенням кількості літніх людей. У багатьох розвинених країнах помітили тенденцію до збільшення кількості старіючого населення, утому числі і в Україні. Сьогодні існує чимало проблем, пов'язаних зі “старінням населення”. У зв'язку з цим наголошується підвищений інтерес до цього вікового періоду життя. Основними небезпеками старості стають: самотність, апатія, жалість до себе, безнадійність, соціальне виключення - руйнування соціальних зв'язків. Внаслідок особливостей старіння викає процес деменції. Згідно з визначенням Всесвітньої організації охорони здоров'я, деменція - це “синдром який зазвичай є хронічний або прогресуючий, під час якого відбувається деградація когнітивної функції (вміння адекватно мислити та аналізувати) більшою мірою, чим очікується при нормальному старінню" (Деменция. Информационный бюлетень, 2018). Встановлено, що деменція призводить не тільки до проблем із пам'яттю, але з часом до зміни особистості, втрати більшості соціальних навиків, зміни поведінки та реакцій на оточуюче середовище. Щорічно 
збільшується частка людей похилого віку по відношенню до загальної частки населення, за прогнозами ООН до 2025 ця цифра становитиме 1,2 млрд. Особливо видиме збільшення чисельності людей літнього віку в Україні, на сьогоднішній день 20,4% людей, які досягли 60-річного віку(“Eurostat Statistics”).Згідно з даними Всесвітньої організації охорони здоров’я, від деменції потерпає 47,5 мільйонів людей у світі. Очікується, що до 2030 року кількість таких людей буде не менше 75,6 млн., а до 2050 - 135,5 млн. 58\% всіх зареєстрованих випадків деменції спостерігають в країнах з низьким або середнім рівнем соціального розвитку. Кількість захворюваних в Україні становить 63 тисячі. Щорічно з такою проблемою стикається 4,5 тисячі осіб. Виникає потреба у профілактиці деменції літніх людей. Можемо припустити, що найочевиднішим чинником для успішного процесу профілактики $є$ організація дозвілля методами соціальної роботи. Серед пріоритетних чинників можна віднести спілкування, яке допомагає зберігати когнітивні та соціальні навики. У цьому контексті важливою є діяльність соціального працівника, яка сприяє зменшенню процесу деменції. Сьогодні питання літніх людей та деменції літніх людей привертають увагу багатьох дослідників. Найбільший внесок зробили фахівці з Білорусії: Прощаев К, Ильницкий А, Рудько И, Хвостова И, Колбасова О, Короткевич Т. Але спостерігається тенденція того, що закордонні автори прагнуть іï вивчати з соціального аспекту, вітчизняні - описують деменцію лише з медичної точки зору, не враховуючих соціальних факторів, які впливають на цей процес.

Під час соціальної роботи з деменцією похилих людей, потрібно приділяти увагу специфіці життєдіяльності літньої людини, яка складається із багатьох факторів, які інколи самі пособі $є$ деструктивними. 3'ясовано, що до таких факторів належить :

1. Погіршення здоров'я.

2. Послаблення психічних функцій. Погіршення концентрації уваги, сповільнення когнітивних процесів, розсіяність призводять до дезадаптації похилої людини до навколишнього середовища.

3. Низький рівень життя. Через низьку пенсійну виплату, літні люди не в змозі забезпечити себе ефективними ліками, підтримувати здорове харчування. Такий рівень життя призводить до відчуття деривації.

4. Зменшення соціальних зв'язків, самотність. Вихід на пенсію означає заміну звичайного життя на такого, де кількість соціальних стосунків та зв'язків мінімізується. Інколи з боку рідних спостерігається небажання спілкуватися із літньою людиною, що призводить до погіршення емоційного стану.

5. Зміна соціальних навиків. Після виходу на пенсію, змінюється коло обов'язків від професійних до домашніх-допомогти у побуті, приготуванні їжі. Така різка зміна призводить до відчуття соціальної самотності в колі родини (Романычев И,2018, с.3).Всі ці фактори можуть і не впливати на психічний стан похилої людини і деменція- один і варіантів прояву соціальнопсихологічного неблагополуччя (Малофеев И.,2013, с.107).

Профілактика деменції спрямована на створення соціальних зв'язків та збільшення комунікаційних відносин. Система соціальних зв'язків для людини з деменцією має не менше значення, ніж рівень життя чи здоров'я. Стабільні соціальні стосунки дають змогу вирішувати як матеріальні, так і побутові питання, а також відіграють важливу роль в соціальнопсихологічній підтримці літньої людини (Сиденкова А., 2007, с.5-8). Вони дають змогу не відчувати себе самотнім, здійснюють інформаційну взаємодію між поколіннями. Кількість знайомств, дружніх контактів, постійні взаємовідносини з родичами та друзями забезпечують емоційну та смислову стабільність повсякденного життя, тим самим блокують подальший розвиток деменції. Такі характеристики як позитивність та інтенсивність соціальних зв'язків впливають на соціально-комунікативне поле в плані впливу на якість життя літньої людини. На нашу думку, залученість індивіда в позитивні соціальні структури - сім'ю, клуби, організації - одна з важливіших умов профілактики літньої деменції.

Методи соціальної роботи з літніми людьми з деменцією передбачають : 
1. Розвиток форм дозвілля, спрямовані на створення умов самореалізації, реалізація творчого потенціалу, розвиток їхньої пізнавальної активності, залучення до нових видів творчої діяльності та активності.

2. Організація клубів за інтересами : кулінарії, комп’ютерних курсів, вивчення іноземних мов, фінансової грамотності, вишивання чи в'язання.

3. Форми соціального туризму : екскурсії, поїздки, віртуальні поїздки з метою підтримки інтелектуальної, пізнавальної активності, збільшення кола спілкування.

4. Заняття лікувальною фізкультурою, кінезотерапією,скандинавською ходьбою,танцями 3 метою підтримки фізичної активності, нормалізації психічного та емоційного стану

5. Залученість до музикотерапії, фототерапії, казкотерапії, мемуаротерапії з метою корекції психічного стану і підтримки інтелектуального рівня.

6. Використання спеціальних методик : арт-терапія, ерготерапія, пет-терапія (“Деменция как новый социальный визов”, 2019,с.107).

Таким чином, комплексна соціально-реабілітаційна робота при вивченні соціальних характеристик літньої людини дає змогу призупинити процес деменції. Наведені вище методи соціальної роботи сприяють тривалому збереженні когнітивних функцій та повсякденній активності людей літнього віку. Процес деменції в Україні є маловивченим, тому для успішної практики потрібно брати до уваги закордонний досвід, але враховувати, що фактори проживання у країнах із різним рівнем життя відрізняються, тому потрібно коригувати відповідно до потреб та особливостей українського старіння.

\section{References}

Dementia. [Electronic resource] / World Health Organization newsletter. - 2017. - Access Mode: https://www.who.int/en/news-room/fact-sheets/ detail / dementia. - Date accessed: 12/19/2018.

Dementia as a new social challenge: a guide for managers and professionals / Belarus Support Program; Research Institute of the Ministry of Labor and Social Security. - Minsk: Kolorgrad, 2019. - 312 p.

Dementia // Encyclopedia of the site on problems of dementia "Memini" [Electronic resource]. - Access mode: https://memini.ru/glossary/27886. - Access Date: 19/11/2018.

Eurostat, Statistics. Explained article «Population and population change statistics [Electronic resource] Access mode: http://ec.europa.eu/eurostat/statisticsexplained/index.php/Population and_population_change_statistics.

Malofeev, I.V. Services in the social service system: theory and practice: monograph / Professional library of a social service worker. - № 6. - M .: Social service, 2013. - 256 p5. 6.Sidenkova, A.P. Late age dementia as an actual psychosocial problem // Social and clinical psychiatry. - 2007. - №4.- P. 5-8.

\section{Список використаних джерел}

Деменция. Информационный бюллетень [Электронный ресурс] / Всемирная организация здравоохранения. - 2017. - Режим доступа : https://www.who.int/ru/news-room/fact-sheets/ detail/dementia. - Дата доступа: 19.12.2018.

Деменция как новый социальный вызов : пособие для руководителей и специалистов / Программа поддержки Беларуси; НИИ труда Минтруда и соцзащиты. - Минск : Колорград, 2019. - 312 с.

Деменция // Энциклопедия сайта по проблемам деменции «Мемини» [Электронный ресурс]. Режим доступа: https://memini.ru/glossary/27886. - Дата доступа : 19.11.2018.

Малофеев, И. В. Услуги в системе социального обслуживания: теория и практика: монография / Профессиональная библиотека работника социальной службы. - № 6. - М.: Социальное обслуживание, 2013. - 256 с.

Сиденкова, А.П. Деменция позднего возраста как актуальная психосоциальная проблема // Социальная и клиническая психиатрия. - 2007. - №4.- С. 5-8. 
Eurostat, Statistics. Explained article «Population and population change statistics [Електроннийресурс] Режим доступу: http://ec.europa.eu/eurostat/statisticsexplained/index.php/Population and_population_change_statistics.

\section{Contact information:}

Олеся Макогін

olesia.makohin@yahoo.com 